\title{
EFFECTS OF DIFFERENT TRAINING LOAD AND TRAINING REGIMENS ON ATHLETES
}

\author{
EFEITOS DE DIFERENTES CARGAS EREGIMES DE TREINO EM ATLETAS
}

Original Article

ARTIGo Original

EFECTOS DE DIFERENTES CARGAS Y REGÍMENES DE ENTRENAMIENTO EN ATLETAS

Artículo Original

\author{
Shuaixian Jiang ${ }^{1}$ (ID \\ (Physical Education Professional), \\ Ming Yang 2 (D) \\ (Physical Education Professional), \\ Ye $\operatorname{Tian}^{3}$ (D) \\ (Physical Education Professional) \\ 1. Key Laboratory of Endurance \\ of the State Sports General \\ Administration, Changchun, Jilin, \\ China. \\ 2. Key Laboratory of Endurance \\ of the State Sports General \\ Administration, Changchun, Jilin, \\ China. \\ 3. Sports Teaching and Research \\ Department, Changchun \\ University of Architecture and Civil \\ Engineering, Changchun, Jilin, \\ China.
}

\section{Correspondence:}

Ming Yang

Changchun, Jilin, China. 13002.

MingYang31@126.com

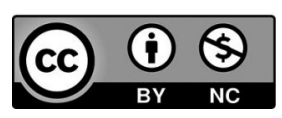

\begin{abstract}
Introduction: The research of different training has always attracted the attention of people in sports circles all over the world. Training for strength testing is also an important part of athletes' physical training. Objective:To explore the effects of different training loads and training ratios on the cardiorespiratory endurance of track and field athletes. Methods: A total of 50 male students from a university were selected for the experiment, 30 from the university's track and field training team, and 20 ordinary students. Results: When the load is $75 \mathrm{~W}, 125 \mathrm{~W}$, or $150 \mathrm{~W}$ there is a significant difference in $\mathrm{R}$ between the first stage and the third stage $(p<0.05)$; when the load of the middle and long distance running team is $25 \mathrm{~W}$ and $125 \mathrm{~W}$, there is a significant difference between the $V E$ of the third stage and the first stage; when the load is $100 \mathrm{~W}$, there is a significant difference in R between the first and second stages $(P<0.05)$. Conclusions: In the exercise load test, the cardiorespiratory endurance and energy metabolism characteristics of the different training teams in the third stage were better than those in the first and second stages. Level of evidence ll; Therapeutic studies - investigation of treatment results.
\end{abstract}

Keywords: Training; Cardiorespiratory Fitness; Athletes.

\section{RESUMO}

Introdução: Investigações buscando diferentes formas de treinamento sempre atraíram a atenção de pessoas nos círculos esportivos pelo mundo. O treino para testes de força também é uma parte importante do condicionamento físico de atletas. Objetivo: Explorar os efeitos de diferentes cargas e regimes de treino na resistência cardiorrespiratória de praticantes de atletismo. Métodos: Um total de 50 estudantes do sexo masculino de uma universidade foi selecionado para o experimento, sendo 30 da equipe de atletismo da universidade e 20 estudantes regulares. Resultados: Com cargas de $75 \mathrm{~W}, 125 \mathrm{~W}$, ou 150W, houve diferença significativa no Rentre o primeiro e o terceiro estágios $(p<0,05)$; quando a carga aplicada ao time de corrida de média e longa distância foi de $25 \mathrm{~W}$ e 125W, houve diferença significativa no VE dos mesmos estágios; quando a carga aplicada foi de 100W, houve diferença significativa no R entre o primeiro e segundo estágios $(p<0,05)$. Conclusões: Nos testes de exercício com carga, a resistência cardiorrespiratória e a energia metabólica das diferentes equipes de treinamento foram melhores no terceiro estágio que no primeiro e segundo estágio. Nível de evidência ll; Estudos terapêuticos - investigação de resultados de tratamento.

Descritores: Educação Física e Treinamento; Aptidão Cardiorrespiratória; Atletas.

\section{RESUMEN}

Introducción: Investigaciones buscando diferentes formas de entrenamiento siempre atrajeron la atención de las personas en los círculos deportivos por el mundo. Elentrenamiento para pruebas de fuerza también es una parteimportante de la preparación fisica de atletas. Objetivo: Explorar los efectos de diferentes cargas y regímenes de entrenamiento en la resistencia cardiorrespiratoria de practicantes de atletismo. Métodos: Fue seleccionado un total de 50 estudiantes del sexo masculino de una universidad para el experimento, siendo 30 del equipo de atletismo de la universidad y 20 estudiantes regulares. Resultados: Con cargas de 75W, 125W $150 \mathrm{~W}$, hubo diferencia significativa en el Rentre la primera y la tercera etapa $(p<0,05)$; cuando la carga aplicada al equipo de corrida de media larga distancia fue de $25 \mathrm{Wy} 125 \mathrm{~W}$, hubo diferencia significativa en el VE de las mismas etapas; cuando la carga aplicada fue de 100W, hubo diferencia significativa en el $R$ entre la primera y la segunda etapa $(p<0,05)$. Conclusiones: En las pruebas de ejercicio con carga, la resistencia cardiorrespiratoria y la energía metabólica de los diferentes equipos de entrenamiento fueron mejores en la tercera etapa que en la primera y la segunda. Nivel de evidencia ll; Estudios terapéuticos - investigación de resultados de tratamiento.

Descriptores: Educación y Entrenamiento Físico; Capacidad Cardiovascular; Atletas.

\section{INTRODUCTION}

The research of different training has always attracted the attention of people in sports circles all over the world, training for strength testing is also an important part of athletes' physical training. Almost all sports events are closely related to athletes' limb movements. ${ }^{1}$ A comprehensive and multi-angle understanding of strength training methods, it can guide us profoundly and effectively in the strength training of track and field sports, this is the basic requirement of modern competitive sports scientific 
training. The understanding of the core at home and abroad is generally similar, basically, they are described around the structure of the human body. ${ }^{2}$ For example, the American physiologist Felipe believes that the core mainly refers to the hip joint, pelvis, and lumbar spine of the human body. ${ }^{3}$

In attaching great importance to the development of track and field sports, has achieved good results in a number of track and field competitions such as hurdles and race walking. With the continuous development of modern competitive sports training scientifically, how to maximize the training effect in track and field training, avoid sports injuries, reasonable adjustment of training load and proportion has become a hot issue in track and field research. ${ }^{4}$

\section{METHOD}

\section{Research object}

According to the principle of voluntary participation, select ordinary male student subjects from a university's track and field training team and non-sports college (professional) as experimental subjects, after PAR-Q (Physical Activity Readiness Questionnaire), the subject requires no serious cardiovascular disease, symptoms of lung or metabolic disease, after screening, 50 people were identified, among them, there are 15 sprinters, there are 15 middle-distance running teams and 20 ordinary students.

\section{Experimental test method}

Use progressively increasing load test (CS 3000) for cardiopulmonary function and gas metabolism test analysis (K4b2 exercise cardiopulmonary function tester), the subject wore a breathing mask and a training computer to sit quietly on a power bicycle for 5 minutes, measure gas metabolism in a quiet state. ${ }^{5}$ Then complete the incremental load exercise on the power bike. At the same time, the three-axis physical activity monitor produced by ActiGraph of the united states is used to test the energy metabolism during exercise and training. The exercise load starts from $25 \mathrm{~W}$, the speed is $60 \mathrm{r} / \mathrm{min}$, each level increases by $25 \mathrm{~W}$, and each level load lasts $2 \mathrm{~min}$, there is no interval between levels, and the heart rate, blood pressure and RPE value at the end of each phase are recorded. ${ }^{6}$

\section{Mathematical Statistics}

All data are processed by SPSS 17.0 statistical software, the difference between samples adopts independent sample t test, the significance level is 0.05 . Analyze the characteristics of cardiorespiratory endurance and energy metabolism among different track and field events.

\section{RESULTS}

\section{Variation characteristics of relative oxygen uptake $(\mathrm{VO} / \mathrm{kg})$ of sprint team at different stages}

From Table 1, it can be concluded that, in a quiet state, the first stage is $9.9 \pm 3.2$, and greater than the second and third stages, during incremental exercise, the relative oxygen uptake of the sprint team at different stages increases with the increase of exercise load. ${ }^{7}$ When the exercise load increases to $175 \mathrm{~W}$, the VO2 of the first stage is $38.0 \pm 1.7$, the $\mathrm{VO} 2$ of the second stage is $41.1 \pm 0.1$, the $\mathrm{VO} 2$ of the third stage is $47.7 \pm 0.8$, after comparing between groups, the VO2 of the second stage and the third stage are significantly different from the first stage $(P<0.05)$, and both are statistically significant .

It can be clearly seen from Figure 1, the relative oxygen uptake of the sprint team has shown an upward trend at different stages, from the quiet state to $150 \mathrm{~W}$, the relative oxygen uptake of the three stages rises at a uniform rate; In the load state of $150 \mathrm{~W}$ to $200 \mathrm{~W}$, the relative oxygen uptake rises fastest in the third stage, and first there was a"sudden increase" and then a slow increase, at 175W, the relative oxygen uptake in the third stage is the largest.

\section{Changes in oxygen pulse (O2P) characteristics of sprint te- ams at different stages}

As can be seen from Table 2, in a quiet state, the O2P of the first stage is $8.4 \pm 2.5$, the O2P of the second stage is $7.2 \pm 4.3$, the O2P of the third stage is $7.2 \pm 1.4$, during the incremental load exercise, the oxygen pulse of the sprint team increases with the increase of exercise load at different stages, but they have their own characteristics. In the second stage, under the load state of $125 \mathrm{~W}$ to $200 \mathrm{~W}$, the change trend of O2P first decreased slightly and then increased suddenly; In the third stage, when the exercise load reaches $125 \mathrm{~W}$, the O2P value is the highest, and then there is a downward trend; In the first stage, the O2P peaks when the load increases to $150 \mathrm{~W}$, and then there is a downward trend.

It can be clearly seen from Figure 2, from a quiet state to when the load increases to 50W, the three stages of O2P have a "burst period", afterwards, they have different characteristics. In the second stage, O2P rises to $150 \mathrm{~W}$ at a constant rate, and then the curve becomes steeper, When it reaches $175 \mathrm{~W}$, there is a downward trend; In the third stage, O2P first rose slowly and then showed a sharp increase trend, reached the top at 125W, then there was a slow downward trend; In the first stage, as the exercise load increases, after O2P slowly rises to $150 \mathrm{~W}$, there will be a downward trend; Under the same level of exercise load (175W), the O2P in the second stage is the largest. ${ }^{8}$

Table 1. Changes in VO2/kg of the sprint team at different stages $(\mathrm{ml} / \mathrm{kg} / \mathrm{min})$ (Mean \pm SD).

\begin{tabular}{c|c|c|c}
\hline Load & One & Two & Three \\
\hline Quiet & $9.9 \pm 3.2$ & $8.4 \pm 2.3$ & $8.4 \pm 4.9$ \\
\hline $25 \mathrm{~W}$ & $13.0 \pm 2.0$ & $12.8 \pm 2.5$ & $12.4 \pm 3.0$ \\
\hline $50 \mathrm{~W}$ & $17.8 \pm 1.4$ & $18.8 \pm 4.0$ & $18.6 \pm 2.7$ \\
\hline $75 \mathrm{~W}$ & $21.8 \pm 2.5$ & $22.5 \pm 1.1$ & $23.2 \pm 2.8$ \\
\hline $100 \mathrm{~W}$ & $26.8 \pm 3.1$ & $28.9 \pm 4.5$ & $28.8 \pm 1.7$ \\
\hline $125 \mathrm{~W}$ & $32.0 \pm 2.1$ & $34.9 \pm 4.8$ & $32.5 \pm 2.5$ \\
\hline $150 \mathrm{~W}$ & $35.6 \pm 4.5$ & $38.1 \pm 2.9$ & $37.2 \pm 4.2$ \\
\hline $175 \mathrm{~W}$ & $38.0 \pm 1.7$ & $41.1 \pm 0.1$ & $47.7 \pm 0.8$ \\
\hline $200 \mathrm{~W}$ & & $43.2 \pm 3.4$ & $50.1 \pm 0.0$ \\
\hline
\end{tabular}

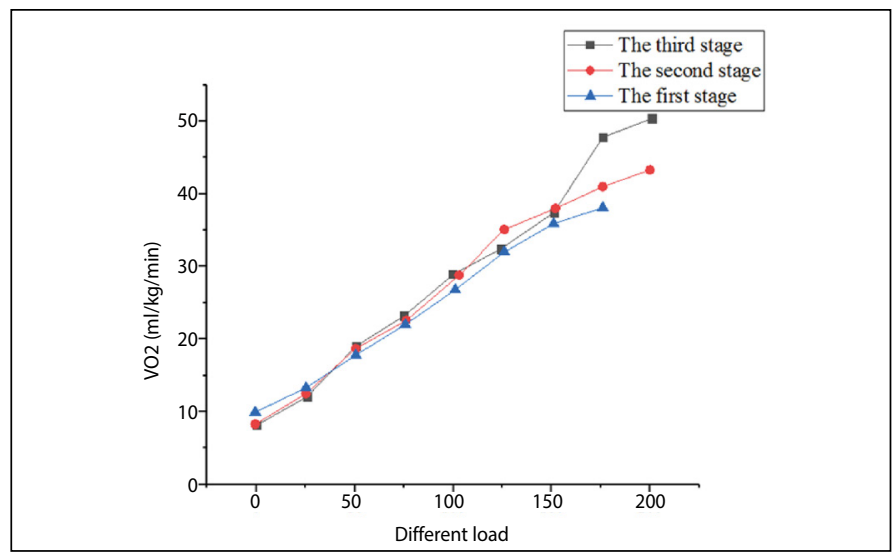

Figure 1. Variation trend of $\mathrm{VO} 2 / \mathrm{kg}$ at different stages under load.

Table 2. Changes in O2P of the sprint team at different stages $(\mathrm{ml})(\mathrm{Mean} \pm \mathrm{SD})$.

\begin{tabular}{c|c|c|c}
\hline Load & One & Two & Three \\
\hline Quiet & $8,4 \pm 2.5$ & $7.2 \pm 4.3$ & $7.2 \pm 1.4$ \\
\hline $25 \mathrm{~W}$ & $9.8 \pm 1.9$ & $10.1 \pm 3.6$ & $0.2 \pm 2.1$ \\
\hline $50 \mathrm{~W}$ & $12.3 \pm 1.7$ & $13.3 \pm 3.6$ & $13.9 \pm 2.9$ \\
\hline $75 \mathrm{~W}$ & $13.5 \pm 1.7$ & $14.6 \pm 3.2$ & $14.7 \pm 0.4$ \\
\hline $100 \mathrm{~W}$ & $14.9 \pm 1.8$ & $15.5 \pm 1.5$ & $16.8 \pm 2.1$ \\
\hline $125 \mathrm{~W}$ & $15.8 \pm 1.6$ & $16.0 \pm 1.2$ & $18.0 \pm 1.8$ \\
\hline $150 \mathrm{~W}$ & $15.8 \pm 1.9$ & $15.9 \pm 1.2$ & $17.2 \pm 1.5$ \\
\hline $175 \mathrm{~W}$ & $14.6 \pm 1.2$ & $18.1 \pm 0.8$ & $17.1 \pm 0.3$ \\
\hline $200 \mathrm{~W}$ & & $18.0 \pm 0.0$ & $15.9 \pm 0.8$ \\
\hline
\end{tabular}




\section{Variation characteristics of the relative oxygen uptake $(\mathrm{VO} / \mathrm{kg})$ of the middle and long distance running team at different stages}

As can be clearly seen from Figure 3, under load, the VO2 of the middle and long distance running team gradually increased in different stages, among them, VO2 in the third stage rises the fastest, has been in a "leading" position, then, when the load increases to $175 \mathrm{~W}$, it rises slowly; The VO2 in the second stage had a sudden increase at 125W, then proceed slowly; During the entire load increase process, the VO2 curve of the first stage is lower than that of the second and third stages.

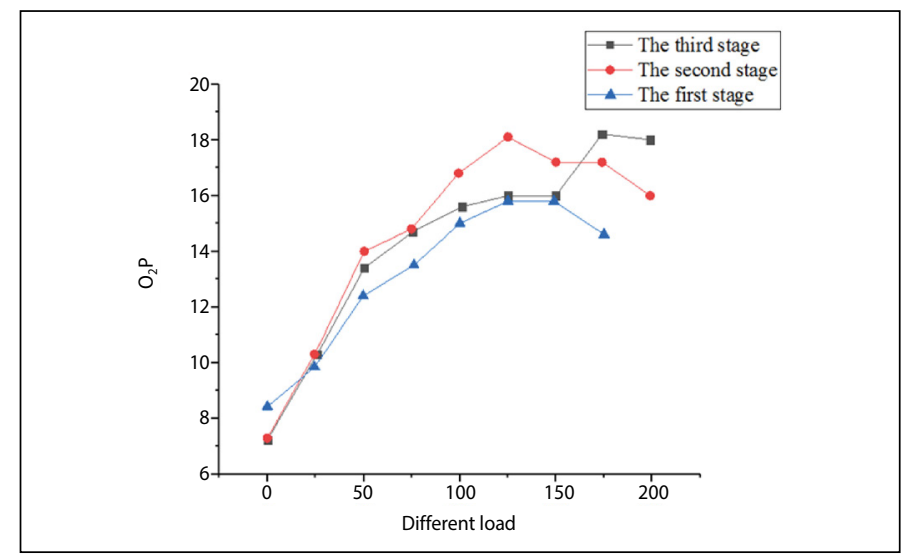

Figure 2. The changing trend of O2P at different stages under load conditions.

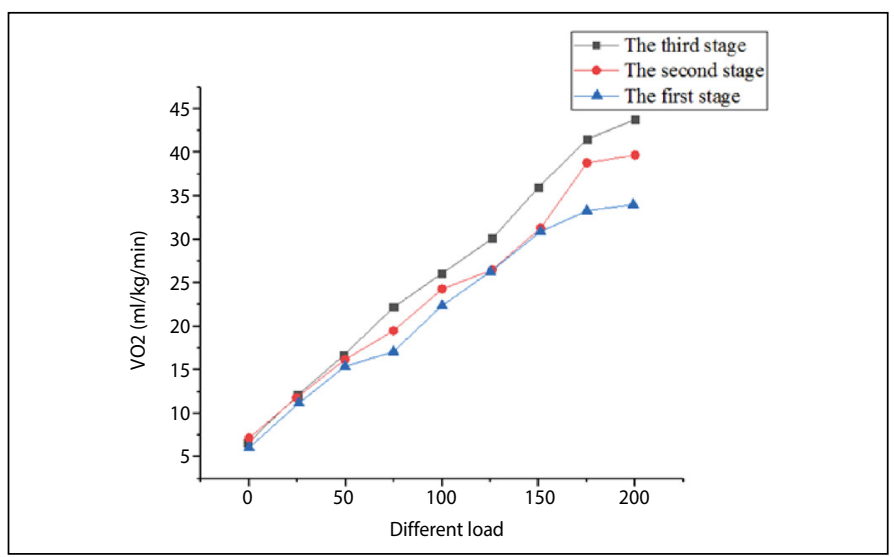

Figure 3. Variation trend of VO2/kg at different stages under load.

\section{DISCUSSION}

Cardiorespiratory endurance is the core element of physical health, cardiopulmonary endurance comprehensively reflects the body's intake, the ability to transport and utilize oxygen. People with good cardiorespiratory endurance can efficiently use the oxygen entering the body, so as to improve the subject's activity ability, on the contrary, people with poor cardiorespiratory endurance are prone to fatigue. ${ }^{9}$ At the same time, cardiorespiratory endurance is the foundation of athletic performance, with good cardiorespiratory endurance, sports performance will improve. The maximum oxygen uptake reflects the human body's maximum aerobic metabolism capacity, reflect the transport capacity of cardiopulmonary function and the ability of muscles to absorb and utilize oxygen, it is an important indicator of the function of the heart and lungs, which is one of the aerobic capacity of the human body..$^{10}$ It refers to the participation of a large number of muscle groups in the body during prolonged and strenuous exercise, take care of lung function and muscle use of oxygen to reach the final level of the subject, the amount of oxygen that can be absorbed per unit time. Some studies believe that, the long-term endurance training can increase the human body's maximum oxygen uptake to a certain extent, and can improve their athletic performance.

\section{CONCLUSION}

In short, reasonable adjustment of training load in track and field sports, training ratio, comprehensively consider the improvement effect of athletes through training on physical, psychological, technical and personality abilities, and according to the speed, strength and endurance requirements of track and field sports, combining the differentiated requirements of different sports, design targeted training programs for athletes, in strength training, high load, low-density training strategy, use low load in speed training, a high percentage of training strategies, in endurance training, medium load, a high percentage of training strategies, from the perspective of scientific training, optimize track and field training methods, help athletes achieve better training results.

All authors declare no potential conflict of interest related to this article

AUTHORS' CONTRIBUTIONS: Each author made significant individual contributions to this manuscript. Shuaixian Jiang: writing and performing surgeries; Ye Tian: data analysis and performing surgeries,

Ming Yang: article review and intellectual concept of the article.

\section{REFERENCES}

1. YuTC, Chiang CH, Wu PT, Wu WL, Chu IH. Effects of Exergames on Physical Fitness in Middle-Aged and Older Adults in Taiwan. International Journal of Environmental Research and Public Health. 2020;17(7):2565.

2. Cheng YH, Wei L, Chan WP, Hsu CY, Huang SW, Wang H et al. Effects of protein supplementation on aerobic training-induced gains in cardiopulmonary fitness, muscle mass, and functional performance in chronic stroke: A randomized controlled pilot study. Clinical Nutrition. 2020;39(9):2743-50.

3. Martinez Aguirre-Betolaza A, Mujika I, Fryer SM, Corres P, Gorostegi-Anduaga I, Arratibel-Imaz I et al. Effects of different aerobic exercise programs on cardiac autonomic modulation and hemodynamics in hypertension: data from EXERDIET-HTA randomized trial. Journal of Human Hypertension. 2020;34(7):1-10.

4. Minmin S, Leiming S, Kai Z, Xingke X, Ling H, Lin W et al. Effects of Different Line Spacing and Seedling Belt Width on Yield Formation of Broad-Width Fine Sowing Wheat. Agricultural Biotechnology. 2020;9(3):33-7.

5. Seitz H, Preissler E, Catalá-Lehnen P, Weitl M. Effects of the 'live low-train high' method on variables of endurance capacity. A systematic review. Deutsche Zeitschrift für Sportmedizin. 2020;71(2):43-50.
6. Shei RJ. Training Load Influences the Response to Inspiratory Muscle Training. Journal of Sports Science \& Medicine. 2020;19(4):772-3.

7. Gorzi A, Rahmani A, Mohammadi Z, Neto WK. Effects of different lengths of high-intensity interval training microcycles on the systemic and hippocampal inflammatory state and antioxidant balance of immature rats. Molecular Biology Reports. 2021;48(6):5003-11.

8. Yen-Hsing L, Hiroyuki H, Peter C, Baes M. Geometry effects on dust attenuation curves with different grain sources at high redshift. Monthly Notices of the Royal Astronomical Society. 2021;507(2):2755-65.

9. Tanji F, Ohnuma H, Ando R, Kojima C, Kasai N, Naito T et al. The Effects Of Hypoxic Training At Different Exercise Intensities On Endurance Performance: 2793 Board \#254 May 29 10:30 AM - 12:00 PM. Medicine \& Science in Sports \& Exercise. 2020;52(Suppl 7):773, 2020

10. Oz G, Gunay E, Dumanli A, Cilekar S, Yucens B, Gokaslan S et al. Effects of clipping endoscopic thoraca sympathectomy at Th4 on cardiopulmonary functions, quality of life and psychosocial functions. General Thoracic and Cardiovascular Surgery. 2020;68(5):516-22 